Abstracta Iranica Abstracta Iranica

Revue bibliographique pour le domaine irano-aryen

Volume 31 | 2011

Comptes rendus des publications de 2008

\title{
« Recent Trends in the Historiography of Iran under the Pahlavi Dynasty, 1921-1979 ». History Compass 6/6, 2008, p. 1400-1406.
}

\section{Bianca Devos}

\section{(2) OpenEdition}

1 Journals

\section{Édition électronique}

URL : http://journals.openedition.org/abstractairanica/39605

DOI : 10.4000/abstractairanica.39605

ISSN : 1961-960X

Éditeur :

CNRS (UMR 7528 Mondes iraniens et indiens), Éditions de l'IFRI

\section{Édition imprimée}

Date de publication : 15 mai 2011

ISSN : 0240-8910

\section{Référence électronique}

Bianca Devos, « «Recent Trends in the Historiography of Iran under the Pahlavi Dynasty, 1921-1979 ». History Compass 6/6, 2008, p. 1400-1406. », Abstracta Iranica [En ligne], Volume 31 | 2011, document 182, mis en ligne le 11 octobre 2012, consulté le 30 septembre 2020. URL : http:// journals.openedition.org/abstractairanica/39605; DOI : https://doi.org/10.4000/abstractairanica. 39605

Ce document a été généré automatiquement le 30 septembre 2020.

Tous droits réservés 


\section{« Recent Trends in the} Historiography of Iran under the Pahlavi Dynasty, 1921-1979 ». History Compass 6/6, 2008, p. 1400-1406.

\section{Bianca Devos}

This very helpful article compiles new trends in historical studies about Pahlavī Iran and consists of three parts almost equal in length: a general overview of the historiography of the period from 1921 to 1979, supplemented by extensive endnotes, and finally followed by a bibliography of 63 titles. The first part of the article sketches the hitherto prevailing perspectives on the Pahlavī era, explores the effects of the revolution in 1979 for historical research on the preceding period, and traces the recently changing focus, which moves away from the common state-centered view and takes other social agents into account. Examples of studies with new research approaches and new fields of research are given in an annotated form in the endnotes.

\section{INDEX}

Thèmes : 4.3. Histoire de l'Iran moderne (à partir de 1905) 
AUTEURS

BIANCA DEVOS

Philipps-Universität Marburg 